\title{
PEMBELAJARAN FIQH YANG HUMANIS Analisis terhadap Kurikulum Fiqh MTs
}

\section{Sri Mawarti}

Pengawas Madrasah Tingkat Tsanawiyah Kementrian Agama Kota Pekanbaru e-mail: srimawarti66@gmail.com

\begin{abstract}
Abstrak
Tulisan ini mendiskusikan akan pentingnya upaya mengembangkan model pembelajaran fiqh yang lebih humanis. Pembelajaran fiqh perlu didorong ke arah yang lebih transformatif, mau melihat perbedaan, menyadari tentang pentingnya pluralitas dalam pemahaman fiqh. Oleh karena itu, pembelajaran figh semestinya harus humanis, yaitu menegubkan kembali kepentingan manusia dalam beribadah. Model pembelajaran fiqh yang bumanis diantaranya adalab menekankan akan pembelajaran yang bermakna dan pendekatan dialogis.
\end{abstract}

Kata kunci; Humanis, Fiqh, Pembelajaran

\section{Pendahuluan}

Memperbincangkan dunia pendidikan pada hakikatnya merupakan perbincangan mengenai diri kita sendiri. Artinya, perbincangan tentang manusia sebagai pelaksana pendidikan sekaligus sebagai pihak penerima pendidikan. Perbincangan manusia sampai kapan pun akan tetap aktual dikedepankan, lebih-lebih dalam suasana kemajuan ilmu pengetahuan dan tekonologi dewasa ini.

Manusia adalah makhluk multidimensional. Bukan saja karena manusia sebagai subyek yang secara teologis memiliki potensi untuk mengembangkan pola kehidupannya tetapi juga sekaligus menjadi obyek dalam keseluruhan macam dan bentuk aktivitas dan kreativitasnya. Sebagaimana disebutkan dalam al-Qur'an berikut:

Artinya: "Dan dia Telah menundukkan untukmu apa yang di langit dan apa yang di bumi semuanya, (sebagai rahmat) daripadaNya. Sesungguhnya pada yang demikian itu benar-benar terdapat tandatanda (kekuasaan Allah) bagi kaum yang berfikir" (QS. AlZariyat:13).

Dengan demikian, bentuk dan sistem aspek-aspek kehidupan senantiasa harus dikonstruksi di atas konsep manusia itu sendiri, sehingga diskursus mengenai manusia menjadi menarik tidak saja karena keunikan makhluk yang satu ini, tetapi juga karena kompleksitas daya yang 
dimilikinya sangat luar biasa Baharudin dan Moh Makin, 2007).

Kaitannya dengan upaya memperbincangkan suatu paradigma pendidikan apa pun jenisnya, seyogyanya berangkat dan berorientasi dari kerangka dasar pemikiran tentang manusia. Harapan selanjutnya, pendidikan harus mampu menjadi sarana dan wadah dalam upaya optimalisasi serta aktualisasi potensi kemanusiaan manusia.

Al-Qur'an secara kategorikal mendudukkan manusia ke dalam dua fungsi pokok. Pertama, sebagai 'abd Allah (hamba Allah). Kedua, sebagai khalifah Allah fi al-Ard (wakil Allah di muka bumi) dengan pandangan kategorikal bercorak dualisme-dikotomik. Dengan fungsi sebagai 'abd Allah, sebenarnya al-Qur'an ingin menjelaskan muatan fungsional yang harus diemban manusia dalam melakukan tugas kehidupannya di bumi. Konsep ini lebih mengacu kepada tugas-tugas individual sebagai hamba Allah yang diwujudkan dalam bentuk pengabdian yang bersifat ritual kepada-Nya (QS. AlZariyat: 56).

Manusia paripurna seharusnya dapat menampilkan dua prestasi kesalehan, yakni kesalehan ilmu dan kesalehan amal. Manusia paripurna adalah manusia yang tidak hanya secara vertical function menunjukkan prestasi kesalehan, tetapi dalam realitas faktualnya sebagai horizontal function, manusia harus menunjukkan prestasi kesalehan sosialnya.

Kecuali sebagai 'abd Allah, manusia juga harus melaksanakan fungsi lainnya sebagai makhluk historis. Dalam kerangka ini, al-Qur'an menempatkan manusia sebagai khalifah Allah fi al-Ard. Dalam dimensi ini, Islam memandang manusia dengan pandangan yang positifkonstruktif. Dengan menjabat sebagai khalifah Allah fi al-Ard, al-Qur'an telah memposisikan manusia secara positifkonstruktif untuk senantiasa menciptakan kemakmuran bagi segenap komunitas alam raya ini.

Berangkat dari kerangka konseptual di atas dan kesadaran bahwa untuk mengembangkan potensi insaniyah serta sosialisasi nilai-nilai, ketrampilan dan sebagainya, harus melalui kegiatan pendidikan, maka kita dituntut untuk menyelenggarakan praktik pendidikan yang menjunjung tinggi nilai-nilai kemanusiaan (humanistik).

Pendidikan humanistik dalam pandangan Islam adalah pendidikan yang memandang manusia sebagai manusia, yakni makhluk hidup ciptaan Allah dengan fitrah-fitrah tertentu untuk dikembangkan 
secara maksimal dan optimal (Baharudin dan Moh Makin, 2007).

Sementara ketika kita menengok sistem pendidikan di negeri ini, dalam prakteknya ternyata tidak menempatkan manusia (baca: siswa) sebagaimana mestinya. Dalam proses pembelajaran, siswa kurang didorong untuk mengembangkan segala kemampuan yang dimilikinya, termasuk kemampuan berfikir.

Proses pembelajaran diarahkan kepada kemampuan anak untuk menghafal informasi; otak anak dipaksa untuk mengingat dan menimbun berbagai informasi tanpa dituntut untuk memahami informasi yang diingatnya itu untuk menghubungkannya dengan kehidupan sehari-hari. Akibatnya? Ketika anak didik kita lulus dari sekolah, mereka pintar secara teoritis, tetapi miskin aplikasi. Karena yang terjadi tak lebih proses duplikasi-duplikasi kepribadian dan pengetahuan guru terhadap siswanya. Tidak ada pola-pola baru yang menempatkan siswa sebagai manusia yang unik yang memiliki relung-relung batin yang berbeda. Individualitas anak sebagai personal yang merdeka menjadi kabur (Wibowo, 2008).

Orientasi pendidikan seperti ini harus dikembalikan pada wajah aslinya, yaitu suatu proses transformasi nilai yang humanistik.

Salah satu ide yang penting dalam pendidikan humanistik adalah siswa harus mempunyai kemampuan untuk mengarahkan sendiri perilakunya dalam belajar (self regulated learning), apa yang akan dipelajari dan sampai tingkat mana, kapan dan bagaimana mereka akan belajar. Ide pokoknya adalah bagaimana siswa belajar daripada sekedar menjadi penerima pasif dalam proses belajar (Slavin, 1994).

Dalam pengertian lain, pendekatan humanistik dalam pembelajaran menekankan pentingnya emosi atau perasaan, komunikasi yang terbuka dan nilai-nilai yang dimiliki oleh setiap siswa. Sehingga tujuan yang ingin dicapai dalam proses belajar itu tidak hanya dalam domain kognitif saja, tetapi juga domain afektif dan psikomotorik. Tujuan lainnya adalah bagaimana siswa menjadi individu yang bertanggung jawab, penuh perhatian terhadap lingkungannya, mempunyai kedewasaan emosi dan spiritual (Baharudin dan Wahyuni, 2008:142).

Pendekatan ini menjadi sebuah tawaran yang tepat dalam mengatasi problema pembelajaran fiqih. Di mana ditengarai pembelajaran pendidikan Agama Islam (termasuk fiqih) yang selama ini berlangsung, agaknya terasa kurang 
concern terhadap persoalan bagaimana mengubah pengetahuan agama yang bersfat kognitif menjadi "makna" dan "nilai" yang perlu diinternalisasikan dalam diri siswa, untuk selanjutnya menjadi sumber motivasi bagi siswa untuk bergerak, berbuat dan berperilaku secara konkrit-agamis dalam kehidupan praktis sehari-hari (Muhaimin, 2004).

Demikian juga sebagaimana dikritisi oleh Nurcholis Madjid (2002:25), bahwa materi pendidikan Agama Islam yang ideal adalah materi yang mampu diserap, kemudian direalisasikan oleh siswa dalam kehidupannya sehari-hari. Dengan kata lain, bahwa pendidikan Agama Islam jangan hanya ditekankan pada segi kognitif atau ritus-ritus keagamaan semata, namun ia juga harus mampu menyemaikan nilainilai keagamaan dan membuatnya terwujud nyata dalam tingkah laku dan budi pekerti sehari-hari yang sering disebut al-Ablaq al-Karimah.

Di era globalisasi, kehidupan dan peradaban manusia mengalami banyak perubahan, baik karena pengaruh teknologi yang semakin canggih maupun pengaruh budaya yang mengglobal, maka dalam merespon fenomena itu, manusia berpacu mengembangkan pendidikan baik di bidang ilmu-ilmu sosial, ilmu alam, ilmu pasti maupun ilmu-ilmu terapan. Namun bersamaan dengan itu muncul sejumlah krisis dalam kehidupan berbangsa dan bernegara, misalnya krisis politik, ekonomi sosial, hukum, etnis, agama, golongan dan ras.

Akibatnya peranan serta efektivitas mata pelajaran fiqih di Madrasah sebagai pemberi nilai spiritual terhadap kehidupan keberagaman masyarakat dipertanyakan. Bidang studi fiqih di MTs. yang nota bene memuat aturan-aturan tentang cara beribadah seyogyanya mampu membangkitkan kesadaran beragama siswa. Setelah mempelajari materi dalam fiqih, selayaknya siswa termotivasi untuk mengamalkannya. Namun pada kenyataannya, banyak siswa yang sudah bisa melakukan ibadah semisal t \}aharah, shalat, berdhikir, berdoa dan sebagainya, namun enggan mengamalkannya dalam kehidupan sehari-hari.

Lebih-lebih jika mengacu rumusan dalam UU Sisdiknas Nomor 20 Tahun 2003, bahwa pendidikan keagamaan berfungsi mempersiapkan peserta didik menjadi anggota masyarakat yang memahami dan mengamalkan nilai-nilai ajaran agamanya, dan atau menjadi ahli ilmu agama. Maka menjadi sebuah tantangan lembaga pendidikan Islam untuk merealisasikan tujuan mulia tersebut. Karena sesederhana apapun 
proses pendidikan, ultimate goal-nya haruslah diarahkan pada tujuan mulia, yakni melaksanakan proses pendidikan yang mengoptimalkan potensi dasar kemanusiaan dengan pondasi nilai-nilai religius.

Selanjutnya, manakala kita berbicara tentang manajemen pembelajaran, maka di sana ada tiga komponen penting yakni pertama; manajemen kurikulum, yaitu pengelolaan kurikulum yang berisi materi yang akan diajarkan. Kedua; manajemen proses, yaitu pengelolaan terhadap materi diajarkan. Ketiga; manajemen produk, yaitu pengelolaan terhadap hasil dari proses pembelajaran. Ketiga aspek ini sama pentingnya, karena menjadi satu kesatuan yang membentuk lingkungan pembelajaran.

Satu kesenjangan yang selama ini dirasakan dan dialami adalah kurangnya pendekatan yang benar dan efektif dalam menjalankan manajemen pembelajaran. Namun yang sering terlupakan adalah satu proses tersendiri untuk bisa menjembatani antara kurikulum dan hasil pembelajaran. Yang terjadi selama ini adalah jika guru mengajar, maka diasumsikan pada saat itu siswa akan belajar dan paham. Satu asumsi yang salah, namun jarang sekali ada orang yang mempertanyakan asumsi dasar tersebut (Gunawan, 2004:2).
Pada pendidikan formal, manajemen kurikulum sangat diharapkan mampu meningkatkan prestasi belajar siswa. Prestasi belajar berarti suatu keberhasilan yang diperoleh setelah memperoleh didikan atau latihan tertentu (Passaribu dan Simanjuntak, 1980).

Hal ini mengindikasikan bahwa kurikulum memegang peranan yang penting untuk mencapai keberhasilan suatu pendidikan. Sementara jika melihat realita yang ada mengenai kemerosotan pendidikan di Indonesia sudah terasakan bertahun-tahun. Untuk kesekian kalinya kurikulum dituding sebagai salah satu penyebabnya. Hal ini tercermin dengan keberadaan kurikulum yang kurang terencana dengan matang dan upaya selalu mengubah kebijakan kurikulum, mulai kurikulum 1974 sampai yang terakhir kurikulum 2004 (KBK), diganti dengan kurikulum 2006 (KTSP).

Menjadi menarik kiranya mencari dan mengembangkan model manajemen kurikulum yang tepat untuk diterapkan pada sebuah lembaga pendidikan, khususnya pada tingkat menengah. Karena setiap model kurikulum yang ada tentunya masing-masing mempunyai sisi kelebihan dan kekurangan. Demikian juga pertimbangan apakah manajemen 
kurikulum itu tepat atau tidak sekiranya diterapkan.

Sementara jika melihat beberapa permasalahan pembelajaran fiqih yang penulis kemukakan di atas, maka tentunya ke depan perlu disusun format manajemen pengembangan kurikulum yang lebih komprehensif dan lebih humanis. Berangkat dari pemaparan di atas penulis tertarik untuk meneliti lebih lanjut, sejauh mana perspektif humanistik telah tertanam ke dalam pembelajaran fiqih dengan cara meneliti sistem kebijakan tujuan pembelajaran, dan materi pembelajaran dalam kurikulum fiqih MTs. terkait humanistik.

\section{Humanisasi dalam Pendidikan}

Secara konseptual dan operasional perhatian pendidikan lebih dipusatkan kepada pengembangan SDM secara holistik. Dalam istilah AlQor'an kita kenal dengan sebutan ulul albab, yang menurut Jalaluddin Rahmat (1999:215) berarti “intelektual plus ketakwaan, intelektual plus kesalehan."

Dalam kerangka ini, peserta didik menjadi subjek yang memiliki sejumlah kemampuan untuk memilih dan bertindak. Hal ini merupakan wujud kreatifitas yang harus terpelihara, terpupuk dan terkembang secara optimal. Ini merupakan tema sentral pembahasan konsep pendidikan, yang mana merupakan wahana pengembangan humanisasi yang proses pembelajarannya mampu menciptakan kondisi kehidupan peserta didik untuk berfikir secara sistematis dan bertindak manusiawi.

Hal ini menuntut peran pendidikan yang bersifat fasilitatif, yaitu memberikan segala bentuk fasilitas kepada peserta didik untuk belajar mengembangkan sifat-sifat dan perilaku kemanusiaannya secara holistik. Limas Sutanto (2000:155) dalam tulisannya "pendidikan: antara hominisasi dan bumanisasi" menjelaskan bahwa:

"Jika pendidikan diartikan secara sejati sebagai suatu proses humanisasi, procces of bumanization, harus mempunyai ciri dapat menjamin perwujudan insan manusia yang berpendirian sendiri, memiliki otonomi wajar, merdeka, bebas dari ketergantungan irrasional terhadap faktor-faktor eksternal, memiliki internal locus of control, pusat pengendalian kepribadian di dalam diri sendiri yang andal, dan bebas dari segala perasaan rendah diri yang membelenggu."

Jadi tidak hanya menjadikan insan manusia semakin sempurna dan canggih kemampuan otot, otak dan finansilanya saja, yaitu yang dinamakan dengan hominisasi (Sutanto, 2000:155). Dalam individu manusia terdapat dua posisi diri di hadapan Tuhan. Pertama, 
yaitu sebagai kholifah di mana manusia punya pilihan dan kemauan bebas untuk mengelola alam raya ini sesuai dengan kemampuannya, karena pilihan bebas dan kemauan bebas merupakan bagian dari konstitusi kemanusiaan itu sendiri.

Senada dengan hal di atas, Dr.'Imad al Din Khalil dalam bukunya Al-Tafsir alIslami lil-Tarikh yang dikutip Ma'arif (1995:19) mengatakan bahwa:

"manusia dengan posisinya sebagai kholifah Allah di muka bumi diberikan kekuasaan (quddiro labu) untuk menciptakan peristiwaperistiwa sejarahnya dengan kemampuan dan ikhtiarnya, untuk tujuan negatif ataupun tujuan positif."

Kedua, posisinya sebagai abdun, hamba di mana posisi ini merupakan rambu-rambu bahwa pilihan, kemauan serta kemampuan manusia sebagaimana disinggung di atas adalah tidak pernah mutlak sifatnya. Hal ini sesuai ayat: Dan tidaklah kamu diberi pengetabuan melainkan sedikit.

Ayat ini mencerminkan keterbatasan manusia di hadapan Tuhan Yang Maha Mengetahui. Dari kedua posisi di atas, dalam lingkup yang lebih kecil yaitu dalam konteks pendidikan, dapat dianalogkan bahwa peserta didik yang notabene sebagai subjek pendidikan diberi kesempatan seluas-luasnya dalam mengembangkan bakat, minat, kreativitas yang tentu saja dengan menekankan ajaran tanggung jawab terhadap segala tindakannya, sehingga peserta didik akan menemukan kemandirian dalam menentukan aksi dengan bercermin kepada pantulan daripadanya, sehingga ia selalu waspada. Ajaran seperti ini, yakni ajaran tanggung jawab, diartikan Ismail SM dan Abdul Mukti (2000: 141) sebagai "konsisten dan disiplin melaksanakan apa yang benar atau doing what's right.

\section{Pembelajaran Fiqh Humanis}

Diantara upaya untuk mencapai proses pembelajaran humanis adalah mengembangkan pembelajaran yang bermakna, yaitu pembelajaran tersebut harus bermakna bagi siswa. Artinya apa yang dipelajari harus bermanfaat bagi siswa. Bermakna artinya sesuai dengan kebutuhannya, baik terkait dengan hobi mapun kebutuhan saat itu atau paling tidak siswa yakin akan manfaat itu.

Oleh karena itu penting mengaitkan apa yang dipelajari dengan kehidupan sehari-hari (kontekstual dengan kehidupan sehari-hari) dan dengan menggunakan bahasa yang dapat dimengerti oleh siswa (Samani, 2007). Sehingga dengan mempelajari fiqih, siswa merasakan manfaat dari pelajaran tersebut bagi dirinya, sesuai / relevan dengan kebutuhan, 
minat dan kehidupan siswa bak secara intelektual maupun emosional.

Sebagai contoh dengan mempelajari materi shalat siswa akan mendapat sejumlah manfaat bagi diri dan kehidupannya, berupa: 1) Mengerti dan bisa mempraktekkan shalat dengan benar, yang selanjutnya mampu melaksanakannya dalam kehidupan sehari-hari; 2) Menjadikan dirinya untuk senantiasa yang taat beribadah kepada Allah; 3) Termotivasi untuk selalu mengharap ridho Allah baik harapan akan janji Allah (pahala) kepada orang yang memelihara shalatnya, dan berusaha menghindari murka Allah terhadap ancaman kepada orang yang meninggalkan shalatnya; 4) Dengan shalatnya, siswa dapat membentuk karakter diri yang mampu mengendalikan diri dari perbuatan keji dan munkar, menjadi pribadi yang sehat lahir dan batin, mempunyai kepedulian sosial dan sebagainya.

Kemudian prinsip mengkaitkan materi shalat dengan kehidupannya seharihari adalah misalnya siswa dihadapkan pada realita pengalaman orang-orang yang sukses, bahagia dalam hidupnya karena selalu melaksanakan shalatnya. Banyak orang yang sembuh dari berbagai penyakit setelah melakukan terapi s\}ala $>$ t. Banyak orang yang gagal, stress, jauh merasakan ketenangan dan kedamaian hidup karena meninggalkan s\}ala>tnya, dan sebagainya.
Pembelajaran fiqih perspektif humanistik menghendaki dalam proses belajar mengajar terjadi dialog antara guru dan siswa. Artinya terjadi interaksi yang dinamis antara guru dengan siswa, dan antara siswa dengan siswa lainnya. Sehingga metode yang digunakan guru tidak hanya menggunakan ceramah semata, melainkan bisa divariasikan dengan metode tanya-jawab, diskusi, dan pemecahan masalah.

Dengan pengupayakan pembelajaran yang dialogis ini, maka segala potensi siswa dapat tersalurkan dengan baik. Dari segi kognitif/intelegensi siswa menjadi aktif dalam mencari, menemukan, dan menyimpulkan pengetahuan yang diterimanya. Dari segi psikomotorik siswa terpacu untuk saling mempraktekkan materi yang sedang dipelajarinya secara bersama-sama.

Sehingga segala amalan yang belum betul akan dikritisi dan dibenarkan, karena terjadi dialog sesama siswa, maupun oleh guru fiqih. Sementara dari segi afektif, siswa bisa saling mendiskusikan nilai-nilai apa yang bisa mereka ambil dan kemudian diterapkan dalam kehidupan sehari-hari.

\section{Penutup}

Kurikulum fiqih MTs. yang di dalamnya berupa prinsip-prinsip pengembangan, komponen-komponen pengembangan ditinjau dari perspektif humanistik, sudah mencerminkan ciri-ciri kurikulum perspektif humanistik. Terlebih 
materi fiqih MTs. dalam Standar kompetensi dan Kompetensi Dasar berdasarkan Permenag RI Nomor 2 Tahun 2008, sarat dengan esensi pendidikan humanistik berupa muatan pelajaran yang berorientasi pada aspek berketuhanan (babl min Allah) yang tercermin dalam fiqih ibadah dan aspek perikemanusiaan (babl min al-Nas) dalam fiqih mu'amalah.

Kemudian untuk lebih mempertegas nilai-nilai humanistik, penulis menawarkan dimasukkannya materi fiqih ekologi dalam kurikulum fiqih MTs. (Standar Kompetensi dan Kompetensi Dasar) tersebut. Pembelajaran fiqih MTs. perspektif humanistik memiliki ciri-ciri: Pembelajaran yang bermakna; Pembelajaran yang transformatif; dan Pembelajaran yang dialogis.

\section{DAFTAR PUSTAKA}

Affandi, Khozin., 2007., Hermeneutik dan Fenomenologi Dari Teori ke Praktek. Surabaya: PPS Sunan Ampel Surabaya.

Al-Jurjani, Abu Hasan, 1938., al-Ta'rifat Mesir: Mustafa Al-Bab al-Halabi

Baharudin dan Makin, Moh. 2007., Pendidikan Humanistik Yogyakarta: Ar-Ruzz Media

Baharuddin, dan Wahyuni, Esa Nur., 2008., Teori Belajar dan Pembelajaran, Yogyakarta: ArRuzz Media.

Bleicher, Josef., 2007., Hermenentika Kontemporer: Hermeneutika sebagai Metode, Filsafat, dan Kritik. Yogyakarta: Fajar Pustaka

Depdiknas, 2007., Kamus Besar Bahasa Indonesia Edisi Ketiga. Jakarta: Balai Pustaka

Gunawan, Adi W. 2004., Genius Learning Strategy, Jakarta: Gramedia Pustaka Utama

Hanafi., I., 2012., Oeientasi Fiqhiyah dalam Pendidikan Islam., Jurnal A-Fikra, Vol. 11, No. 1. 20-35

Madjid, Nurcholis., 2002., dalam Rama Furqana (ed), Pendidikan Agama dan Akblak Bagi Anak dan Remaja, Jakarta: Logos Wacana Ilmu.

Manoppo, Yanti K. 2005,. "Nilai-nilai humansitik dalam interaksi dosen dan mahasiswa IAIN Sultan Amai Gorontalo", (Tesis, Program Pascasarjana IAIN/UIN Alaudin Makasar

Muhaimin, 2004., Paradigma Pendidikan Islam: Upaya mengefektifkan 
Pendidikan Agama Islam di Sekolah

Bandung: Remaja Rosdakarya

Mukhtar, 2007., Bimbingan Skripsi, Tesis dan

Karya Ilmiah Jakarta: Gaung

Persada Press.

Pasaribu, J.J. dan Simanjuntak, B.., 1980., Proses Belajar dan Mengajar Bandung: Tarsito.

Riyanto, Yatim., 2001., Metodologi Penelitian Pendidikan Surabaya: SIC

Robingatin, 2004., "Psikologi Transpersonal, Suatu Perspektif tentang Dimensi Spiritual Manusia dan Implikasinya terhadap Pendidikan Islam", Tesis, Program Pascasarjana UII Yogyakarta

Sanaky, Hujair AH. 2002., "Pembaharuan Pendidikan Islam menuju Masyarakat Madani Indonesia (Tinjauan Sosio-Kultural Historis)", Tesis, Program Pascasarjana UII Yogyakarta

Sunarto, 2001., Metodologi Penelitian Ilmuilmu Sosial dan Pendidikan Surabaya: UNESA University Press.

Slavin, Robert K. 1994, Educational Pshicology: Theory into Practice Prentice Hall: Engelwood

Wibowo., Agus, 2008, Malpraktik Pendidikan, Yogyakarta: Genta Press 